\title{
MULTIMODALITY AND THE CONSTRUAL OF REALITY IN POLITICAL CARTOONS - THE CASE OF SERBIA-EU RELATIONSHIP
}

\author{
UDC 81'42:741.5(497.11)
}

\section{Tatjana Đurović, Nadežda Silaški}

Faculty of Economics, University of Belgrade, Serbia

\begin{abstract}
Complementing the broad framework of Conceptual Metaphor Theory (Lakoff \& Johnson 1980; Johnson 1987; Benczes, Barcelona, \& Ruiz de Mendoza Ibáñez 2011; etc.) and Critical Metaphor Analysis (Charteris-Black 2004; Musolff 2006) with research on multimodality from a cognitive viewpoint (Forceville 1996, 2008; Forceville \& UriosAparisi 2009; Bounegru \& Forceville 2011; etc.), in this paper we address the topic of Serbia-EU relations unfolded in pictorial and multimodal discourse in news media in order to explore how this topic is communicated via metaphors and other cognitive instruments in newspaper cartoons. The data collection for our analysis consists of 15 cartoons published in the Serbian daily newspaper Politika in the period 2009-2015, which depict the concept of the EU in relation to Serbia and the varied political and social issues associated with it. Modelling our method of analysis on Bounegru and Forceville (2011), we try to show not only how pictorial and multimodal metaphors reveal the underlying metaphor scenarios, those of JOURNEY, SCHOOL, SPORT and LIQUID, but also how multimodal discourse becomes a powerful tool of conveying different evaluative content and rhetorical impact when set within a specific socio-political context.
\end{abstract}

Key words: multimodal metaphor, political cartoons, Serbian, Serbia-EU relations

\section{INTRODUCTION}

Although research into multimodal discourse has been extensive in many genres, political cartoons have received relatively little scholarly attention so far. Still, there have been several studies (e.g. Bounegru \& Forceville 2011; Forceville 2005; El Refaie 2003; Negro Alousque 2013) which pertain to the ways this example of multimodal discourse communicates with readers in order to construct a desired view of political and social reality through metaphors. Lakoff and Johnson's (1980) claim that metaphor is not just a matter of language but an essential feature of our mind gives full relevance to the opinion

Submitted November $30^{\text {th }} 2016$, accepted for publication December $21^{\text {st }}, 2016$

Corresponding author: Tatjana Đurović

Faculty of Economics, University of Belgrade, Serbia

E-mail: gtdjuro@eunet.rs 
that in addition to language, conceptual metaphor can manifest itself in other, non-verbal modes of communication. Thus, complementing the broad framework of Conceptual Metaphor Theory (Lakoff \& Johnson 1980; Johnson 1987; Benczes, Barcelona, \& Ruiz de Mendoza Ibáñez 2011; etc.) and Critical Metaphor Analysis (Charteris-Black 2004; Musolff 2006) with research on multimodality from a cognitive viewpoint (Forceville 1996, 2008; Forceville \& Urios-Aparisi 2009; Bounegru \& Forceville 2011; etc.), in this paper we address the topic of Serbia-EU relations unfolded in pictorial and multimodal discourse in media in order to explore how this topic is communicated to readers via metaphors and other cognitive instruments in political cartoons. Modelling our method of analysis on Bounegru and Forceville (2011), we try to show how pictorial and multimodal metaphors reveal the underlying metaphor scenarios, those of JOURNEY, SCHOOL, SPORT and LIQUID. We also aim to demonstrate how multimodal discourse becomes a powerful tool of conveying rhetorical impact and different evaluative content when set within a specific socio-political context. Therefore, in addition to examining both visual and verbal instances of metaphors and other cognitive instruments pertaining to Serbia-EU relations, we attempt to determine how the identified multimodal cognitive devices help shape both group and national identities and foreground a particular construal of reality which appears to be based on unequal power relations.

\section{THEORETICAL BACKGROUND}

Although Conceptual Metaphor Theory has been widely and critically assessed over the last decade (see e.g. Kövecses 2008; Gibbs 2011; etc.), our application of CMT stems from the original Lakoff and Johnson's (1980) views in which the claim is made that metaphors are a property of not words but of concepts and that, as such, they enhance understanding of particular concepts and ideas. In cognitive linguistic terms, one conceptual domain - the target, is understood in terms of another conceptual domain - the source, where a "conceptual domain" refers to "any coherent organization of experience" (Kövecses 2002: 4). While rather neglected at the very onset of cognitive linguistic research, metonymy has gradually begun to be considered an equally important cognitive device for influencing the way we think. Many authors have claimed that it is "a cognitive phenomenon that may be even more fundamental than metaphor" (Panther \& Radden 1999: 1). Although disagreements still arise among cognitive linguists concerning many unresolved issues surrounding metonymy as a cognitive mechanism, it has now been widely accepted that "metonymy plays a crucial part in the motivation of numerous conceptual metaphors" (Benczes, Barcelona, \& Ruiz de Mendoza Ibáñez 2011: 2). Unlike metaphor, which entails a mapping between two conceptual domains, where the source is used to structure the target, metonymy, on the other hand, is, according to the standard cognitive linguistic view, understood as a conceptual projection whereby one domain is partially understood in terms of another domain included in the same experiential domain (Barcelona 2000). In addition to metaphor and metonymy, image schemas also play a vital role in understanding and structuring the concept of Serbia's EU accession, thus adding to "conceptual interaction" (Ruiz de Mendoza Ibáñez 1997) and frequently the parallel activation of these three cognitive instruments. Johnson defines an image schema as "a recurrent pattern, shape, and regularity in, or of [...] ongoing ordering activities" (Johnson 1987: 29) such as our actions, perceptions, and conceptions. More specifically, an image schema is a spatial abstraction that arises from everyday bodily 
experience (see also Lakoff 1987; Ruiz de Mendoza Ibáñez 1997). Among a number of image schemas provided by Johnson (1987: 126), pertinent to our multimodal analysis of political cartoons depicting Serbia-EU relations are the VERTICALITY, PATH/MOVEMENT and CONTAINER schemas. The VERTICALITY schema "emerges from our tendency to employ an UP-DOWN orientation in picking out meaningful structures of our experience" (Johnson 1987: xiv) and is based on a dichotomy, with the positive pole perceived as UP and the negative pole perceived as DOWN. The PATH image schema consists of a source or starting point, a destination or an end point, and a direction. An internal logic of this schema is that if you go from a source to a destination along a path, then you must pass through each intermediate point on the path (Lakoff 1993). MOVEMENT is an important notion of the PATH image schema, here viewed as the movement of Serbia-as-a-traveller towards the EU as a destination. Finally, the CONTAINER image schema, with its three structural elements - an interior, an exterior and a boundary, is organised around this basic logic: the boundaries prevent what is outside from affecting the entity or entities found within the container or bounded region; everything is either outside or inside the container; if container $\mathrm{A}$ is in container B and B in C, then A is inside C (see Lakoff 1987: 272). More importantly, image schemas used in the construction of visual metaphors and metonymies tend to co-occur, which our analysis of political cartoons will corroborate.

The recent research on metaphoricity tends to shift focus from metaphor being used exclusively in verbal texts to discourses where language, i.e. verbal expressions are one of the communicative modes. This has led to the formulation of the theory of multimodal discourse, also deployed in the paper. Thus, Forceville (2009) argues that if verbal metaphors are manifestations rather than reduplications of thought, one of these manifestations may be non-verbal or pictorial. Unlike monomodal metaphors, such as the prototypical verbal metaphors, "non-verbal metaphors often have targets and/or sources that are cued in more than one mode simultaneously" (Forceville 2009: 24). Since political cartoons in newspapers can hinge on only two modalities (verbal and visual), metaphors in our analysis belong to either monomodal metaphors, i.e. either pictorial/visual metaphors, or to multimodal metaphors, composed of both the verbal and visual modalities (Bounegru \& Forceville 2011). It is also worth emphasising that the motivation for mapping the source domain onto the target domain in multimodal metaphors goes well beyond the notion of embodiment, which is so widely used in CMT to provide concreteness to the source domain. Rather, as Forceville claims, knowledge about source domains is also a matter of cultural connotations "that are metonymically related to a source domain [and] are often more important for potential mappings to a target than its embodied aspects" (Forceville 2009: 28). This is in line with Kövecses' claim that "[m]etaphors are not necessarily based on bodily experience - many are based on cultural considerations and cognitive processes of various kinds" (Kövecses 2005: 4). Our analysis of political cartoons related to Serbia-EU relations will also show that the source domains of multimodal metaphors and metonymies are grounded both in our physical experience and cultural contexts, whereas their interpretation is highly dependent on the prior knowledge of social and political circumstances of the setting in which the cartoons are published.

Finally, in the paper we also employ Musolff's concept of "metaphor scenario", which "constitute[s] an essential feature of metaphor use in public discourse registers" (Musolff 2006: 28). Metaphor scenarios "help to shape the course of public debates and conceptualizations of political target topics by framing the attitudinal and evaluative 
preferences in the respective discourse communities" (Musolff 2006: 28), which is of special importance to the analysis of political cartoons.

\section{Political CARTOONS}

El Refaie (2009b: 184-5) defines a political cartoon as "an illustration, usually in a single panel, published in the editorial or comments pages of a newspaper" addressing "a current political issue or event, a social trend, or a famous personality, in a way that takes a stand or presents a particular point of view". On the one hand, political cartoons "tell an imaginary story about a make-believe world", while on the other, "they refer to real-life events and characters" (El Refaie 2009b: 186). This relationship between the real and the imaginary is metaphorical in nature, "inviting people to map properties from a more tangible area of reality onto one that is more abstract" (El Refaie 2009b: 186). This property of political cartoon genre makes it prone to being analysed from a cognitive linguistic perspective.

The main features of political cartoons are nicely summarised by Negro Alousque (2013: 370) who points out, among other things, that "factual knowledge is essential for their correct interpretation". Without knowledge about the recent event the political cartoon depicts, the reader may not be expected to understand the meaning conveyed by the cartoonist, especially because this genre "generally contain[s] an element of irony or at least something incongruous or surprising" (El Refaie 2009b: 185). This recent political or social event, as pointed out by Negro Alousque (2013: 370), is intertwined with an imaginary world in such a way that "cartoons act as a bridge between fact and fiction" (Edwards 1997: 8, quoted in Negro Alousque 2013: 370). In order to interpret the intended meaning, the reader needs to be involved in the "metaphorical process of transferring meaning from the make-believe to the real world". In political cartoons, this is "conveyed predominantly in the visual mode", although "most cartoon metaphors also rely to some extent on verbal cues" (El Refaie 2009a: 174). This makes this genre a prime example of multimodal discourse.

There are several reasons for our decision to base our analysis on the political cartoons published in the Politika. Firstly, various events which shape Serbia-EU relations are being consistently dealt with, not only verbally but also visually, in the genre of political cartoons published in Serbian news media. Secondly, the given topic is rendered not only via monomodal metaphors, but multimodal metaphors of the verbo-pictorial type as well. Thirdly, metaphor as well as other cognitive instruments are represented in their visual modality to structure various issues, mostly those pertinent to Serbia's attempts to join the EU. Finally, all the selected cartoons are pronouncedly evaluative in character, stemming from the integration of text and image or symbol displayed in this genre.

Our paper, therefore, may be understood as a contribution to the research into metaphors and other cognitive instruments used in political cartooning in a political context which is rife with events that easily render themselves for metaphorical and satirical presentation. 


\section{Data COLlection AND Method}

The data collection for our analysis consists of fifteen cartoons published in Serbian daily newspaper Politika ${ }^{1}$ in the period 2009-2015. More specifically, the paper focuses on those cartoons on the front page of the Politika's Sunday edition whose author is Dušan Petričić. ${ }^{2}$ The selected fifteen cartoons are part of a wider collection which comprises thirty cartoons featuring Serbia-EU relations and the varied political and economic issues associated with them by way of persuasive images accompanied with textual messages and symbols. In the thirty cartoons dating from the given period, the topic of Serbia-EU relations and Serbia's EU accession in particular (the target domain) was either verbally anchored, in the caption and/or the accompanying textual message, or visually rendered by suggestive images or symbols which cued the topic under consideration. Some cartoons contain concurrent verbal and visual representations of the target domain. However, in this paper we focus on four major metaphor scenarios used in the selected fifteen cartoons to structure the complex relations between Serbia and the EU - SCHOOL, SPORT, JOURNEY and LIQUID. The SCHOOL scenario is exemplified by three cartoons, published in the $29^{\text {th }}$ August 2010,12 $12^{\text {th }}$ September 2010 and $29^{\text {th }}$ November 2015 Sunday issues of the Politika. Four cartoons are instances of the SPORT scenario and they were published on $28^{\text {th }}$ August 2011, $25^{\text {th }}$ December 2011, $23^{\text {rd }}$ September 2012, and $30^{\text {th }}$ August 2015 , respectively. As many as six cartoons (published in the $14^{\text {th }}$ June $2009,19^{\text {th }}$ July $2009,19^{\text {th }}$ September 2010, $22^{\text {nd }}$ May 2011, $10^{\text {th }}$ June 2012, and $23^{\text {rd }}$ March 2014 issues of the Politika) illustrate the JOURNEY scenario. Finally, the LIQUID scenario is represented by two cartoons, published on $20^{\text {th }}$ October 2013 and $24^{\text {th }}$ August 2014, respectively. Due to space constraints we discuss five cartoons, representing all scenarios respectively. As already mentioned, the scenarios describe the perception of Serbia-EU relations by the Serbian general public, according to the author of cartoons Dušan Petričić, who offers a critical perspective on the current socio-political events.

One of the most contentious issues in Serbia-EU's relations is the status of Kosovo, now an independent state but still not recognised as such by the Serbian authorities, which is conceived of as an impediment to Serbia's EU accession. Thus, as our analysis of the selected cartoons will reveal, a majority of cartoons pivot on the Kosovo topic which frames Serbia-EU relations and serves to communicate the nature of this relationship by way of suggestive pictorial and multimodal metaphors.

Using a metaphor identification procedure presented by Bounegru and Forceville (2011) and modelling our method of analysis on the method used by the same authors for the analysis of metaphors in editorial cartoons representing the global financial crisis, we aim to do the following:

1. classify both visual and verbal instances of metaphors and other cognitive instruments pertaining to Serbia-EU relations to establish the predominant metaphor scenarios used to depict this issue in political cartoons, and

2. determine how the identified multimodal cognitive devices help shape both group and national identities and foreground a particular construal of reality, which appears to be based on unequal power relations.

\footnotetext{
${ }^{1}$ All cartoons are available at http://www.politika.rs/scc/authors/satires/849

${ }^{2}$ Dušan Petričić was the Politika's cartoonist from 2009 to October 2016.
} 


\section{ANALYSIS}

\subsection{The SCHOOL scenario}

The first cartoon (Figure 1) with the caption "Make-up exam" (dating from $29^{\text {th }}$ August 2010) sets the SCHOOL scenario, frequently deployed in Serbian EU accession discourse. As attested in previous research (see Đurović \& Silaški 2014), this discourse stresses the aspect of unequal power relations. The major SCHOOL scenario may be more specifically verbalised as THE EU ACCESSION PROCESS IS SERBIA'S TAKING A MAKE-UP EXAM ADMINISTERED BY THE EU AS A TEACHER metaphor. The cartoon relates to the period July-September 2010 when the Serbian authorities, trying to prevent the Kosovar side to pass a resolution in the UN General Assembly that would clearly establish Kosovo's independence, passed their own resolution (on $28^{\text {th }}$ July 2010). This was done without prior consultations with not only the EU that Serbia hopes to join (though, out of 28 EU member states 23 recognise Kosovo's independence) but also the US and Russia. This move of the Serbian side

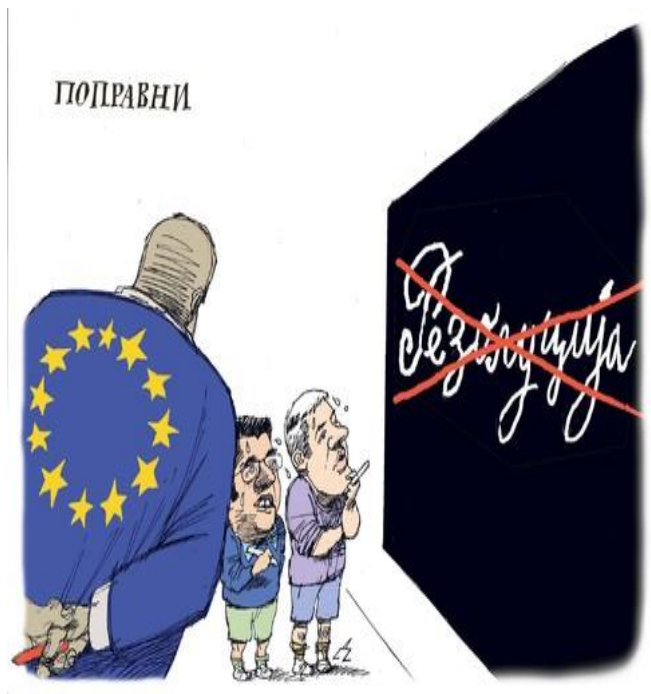

Fig. 1 Politika, 29 ${ }^{\text {th }}$ August 2010, Caption: make-up exam raised eyebrows in the EU, and the EU reacted by requiring the Serbian authorities to amend the text of resolution in such a way that would make it a compromise UN resolution on Kosovo and harmonise with the EU opinion. Hence the cartoon depicts the aftermath of the Serbian government carrying the original resolution, viewed by the EU as a bad and unexpected move. It shows the two people, labelled as the main culprits of this "misunderstanding" with the EU and its potential grave consequences: Boris Tadić, the then President of Serbia, and Vuk Jeremić, in his official capacity as the then-Serbian Minister of Foreign Affairs. They are both metaphorically represented as two students, metonymically standing for Serbia (via the PERSON FOR INSTITUTION metonymy), and thus cue the source domain pictorially. That Serbia-as-a-student did not do her 'school assignment' correctly is both visually and verbally signalled. As for the visual cue, the word "Resolution" on the blackboard is crossed out by the EU-as-a-teacher, metonymically represented by the figure clad in a blue jacket with 12 golden stars on its back, a clear symbol of the EU flag. The verbal cue is the caption "Make-up exam", so we classify this cartoon as a monomodal metaphor since the caption is the verbal instantiation of the same source domain visually rendered - the SCHOOL domain. The connotations arising from the cartoon are that Serbia (metonymically coded by the two top officials), is a student who fails to accomplish her assignment, as judged by the teacher - the EU, which is in a position to ground the student Serbia by asking her 'to take the exam again'. Mappings thus include 'disobedient', 'difficult to control', 'discipline'. The cartoon accentuates asymmetric power relations between the teacher - the EU, and the student(s) - Serbia, also visually rendered by the size of the two Serbian officials versus the size of the EU figure, underlining a 
sharp polarity where one side is in control while the other is controlled and needs to be disciplined.

The second cartoon (Figure 2), also belonging to the loaded $\mathrm{SCHOOL}$ scenario, dates from $12^{\text {th }}$ September 2010 and again shows the figure of the then President of the Republic of Serbia, Boris Tadić, a visual metaphorical instantiation of an art student and a metonym for Serbia (the PRESIDENT FOR A COUNTRY metonymy), practicing drawing in an art class. The metaphor belonging to this scenario can be rendered as THE EU ACCESSION PROCESS IS TEACHING A DEFIANT STUDENT SERBIA. The president is trying to present on the canvas the set 'assignment' - two separate objects, one representing an image of Serbia and the other the image of Kosovo. His work is

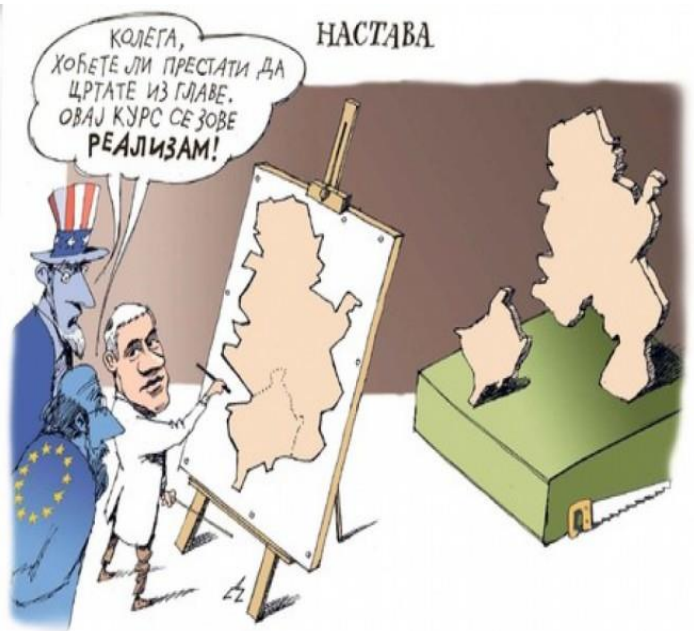

Fig. 2 Politika, $12^{\text {th }}$ September 2010, Caption: Teaching supervised by the two 'teachers' one standing for the US, as displayed by the figure of Abraham Lincoln and his identifiable tall hat in the colours of the American flag, while another one stands for the EU, manifested by the figure's blue jacket with the golden stars on the back - again, a clear symbol of the EU flag. The satirical effect is visually and verbally reinforced - it is achieved not only by Tadić's doing his assignment wrongly, where instead of presenting Kosovo severed from Serbia as in the proposed model he draws them as being one unified whole. This satirical effect is also reinforced by the text simultaneously produced by both American and the EU officials, which reads: "Colleague, will you stop drawing from your head [from your own imagination]. The title of this course is REALISM!" Although the caption "Teaching" clearly corresponds to the visual rendering of the cartoon and the SCHOOL scenario, we classify this cartoon as a multimodal metaphor since the text produced by the metonymical representations of the US and the EU helps to unambiguously view these two figures as teachers. The way the role of the EU as regards the Kosovo issue is perceived in Serbia is effectively manifested by the text simultaneously uttered by both American and the EU officials and the word 'realism' being visually stressed in bold type, which again underscores who has the power to 'model' the international relations according to their own sense of reality. This is also nicely suggested by the image of a saw used to forcibly separate a wooden model of Kosovo from the rest of Serbia.

Similarly to the previous cartoon, which belongs to the same SCHOOL scenario, the mapped connotations are 'strict (teachers)', 'defiant', 'lack of control'. 


\subsection{The SPORT scenario}

The $25^{\text {th }}$ December 2011 cartoon (Figure 3) published in the Politika exemplifies the SPORT scenario, which may be more precisely verbalised as THE EU ACCESSION PROCESS IS A 100M RACE REFEREED BY ANGELA MERKEL metaphor. It depicts a runner, clad in a sport suit whose colours cue the Serbian flag and wearing a national head wear, $\check{s} a j k a c ̌ a$, thus metonymically standing for Serbia. The EU is represented via a double metonymy - Angela Merkel, portrayed here as an umpire, and a sign which resembles the EU flag - metonymy THE EU FLAG FOR THE EU. The image of the runner, a metonym for Serbia, running in the direction opposite of the one shown by the sign indicating where the EU is,

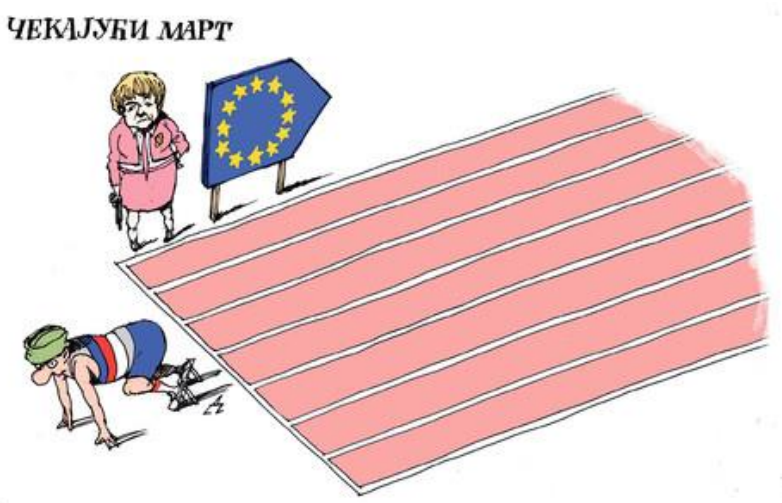

Fig. 3 Politika, $25^{\text {th }}$ December 2011, Caption: Waiting for March as well as of Mrs Merkel still waiting to fire the starting gun and thus mark Serbia's race to the finish line and her final destination, should imply that Serbia is still far from the ultimate goal - entering the EU. This is also suggested by the image of unfinished tracks, hence signalling a long and uncertain race till the very end. The verbal cue, the caption "Waiting for March" is an allusion to $1^{\text {st }}$ March 2012, when the European Council decided to grant Serbia a candidate status to join the EU. This verbal cue classifies the cartoon as a multimodal metaphor. The visual representation of Mrs Merkel as an umpire holding the starting gun highlights the aspect of control and of setting the tempo of Serbia's progress towards the EU accession. The metonymic representation of Serbia, on the other hand, facing the direction opposite of the running tracks should connote that Serbia is still very far from her finish line and sought-after goal - full membership with the EU.

\subsection{The JOURNEY scenario}

The $19^{\text {th }}$ September 2010 political cartoon (Fig. 4) features the MOVEMENT image schema and the more specific SERBIA'S PROGRESS TOWARDS THE EU IS TRAVELLING ON A LONG AND BUMPY ROAD metaphor. This multimodal metaphor of verbo-pictorial type, portrays a figure of the then president of the Republic of Serbia, Boris Tadić (the PRESIDENT FOR A COUNTRY metonymy), standing at the end of the road, puzzled how to proceed further as the traffic signs which are expected to point out what

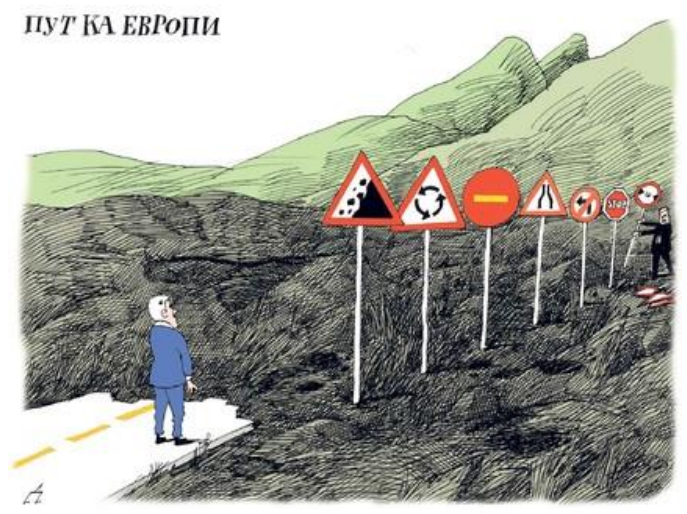

Fig. 4 Politika, $19^{\text {th }}$ September, 2010, Caption: The road to Europe 
direction to take are placed on what looks like a very hostile terrain with high mountains in the background. The verbal rendering, the caption "The road to Europe", is necessary to decode the meaning of the cartoon and particularly of the image of the traffic signs. The selection and the order of the road signs (landslide, roundabout, one-way street, no-left turn, stop signs) are indicative of the journey Serbia needs to embark on to reach the final destination - the EU. All the signs connote the obstacles on the road to the EU, metonymically standing for different unresolved issues. As implied by the figure in the distance about to put up a new traffic sign, the road to Europe will be a very long and bumpy one, which would continue the series of prohibitory and warning signs. The image of the deliberate placing of the traffic signs together with the verbal "The road to Europe" should foreground various impediments that will block or slow down Serbia's motion to arriving at a destination - the EU. It also communicates an overwhelming feeling of the Serbian public that no matter how many hurdles Serbia has overcome the EU may always set up a new one thus manifesting that if eventually Serbia is granted full membership with the EU it will be grudgingly not willingly.

\subsection{The LIQUID scenario}

The last political cartoon (Figure 5), dating from $20^{\text {th }}$ October 2013, illustrates the LIQUID scenario, which renders the more specific EU ACCESSION PROCESS IS DROWNING OF SERBIA BY KOSOVO AS A DEAD WEIGHT metaphor. It rests on the image of a drowning man, metonymically representing the Serbian people, again visually signalled by the national cap šajkača. On a conceptual level, the cartoon is a realisation of the VERTICALITY image schema. A visual metonym for Serbian people relates to the BAD IS DOWN metaphor where, as decoded by the text produced by one of the figures standing by the water, Kosovo is viewed as the burden which, unless Serbia gets rid of it, will drag her to the bottom. The water surrounding the figure is, conceptually speaking, Serbia-asa-container metaphor (based on the COUNTRY IS A CONTAINER metaphor) filled with problems viewed as water (drawing on the PROBLEMS AS STATES ARE CONTAINERS and PROBLEMS ARE LIQUID metaphors). Another pole of the verticality schema belongs to two figures that realise HAVING CONTROL OR FORCE IS UP and the POWER IS UP metaphors.

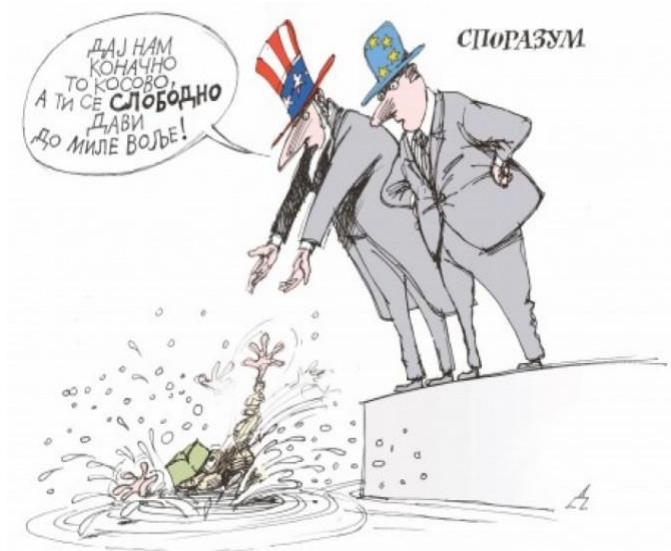

Fig. 5 Politika, 20 ${ }^{\text {th }}$ October 2013, Caption: The agreement
They are metonymical representations of the US and the EU, cued by the hats standing for their respective flags. The cartoon is not easily readable without the verbal renderings - the text uttered by the American figure who says "Give us this Kosovo once and for all, and you can freely drown yourself as much as you wish!", together with the caption "The agreement", make this cartoon an instance of multimodal metaphor.

The body language of the European figure - his hands on his hips - signals superiority over the man in the water. The caption "The agreement" effectively manifests how the seemingly 
innocuous words in a particular socio-political context may turn into a tool for exerting control and social power over another group. 'The agreement' is a unilateral one, a sardonic reminder of the overwhelming influence of the EU (together with the US) on Serbia's vital political and economic issues, while the visual solution which rests on the VERTICALITY schema serves to buttress a rigid dichotomy between dominance and weakness.

\section{DISCUSSION}

Our small-scale analysis shows, firstly, that all the selected cartoons activate both metaphor and metonymy, metaphor being either verbally or visually rendered or present in both modalities, while metonymy is always visually cued. The monomodal/pictorial and multimodal metaphors hinge on various aspects of the target domain - Serbia's EU accession process. Thus, for example, in both cartoons exemplifying the SCHOOL scenario metaphors focus on highlighting the aspect of reprimand and punishment, depicting Serbia as a disobedient student and the EU as a stern teacher. Secondly, the reading of the cartoon proves to be heavily contingent on the viewer's knowledge of particular social and political events, and the interplay between metaphor and metonymy may create a strong emotional impact. Thirdly, all the cartoons analysed as visual and/or verbal instantiations of the SCHOOL, SPORT, JOURNEY, and LIQUID scenarios and marked by the symbols as metonyms deeply culturally entrenched highlight a critical stance of the author of cartoons on Serbia-EU relations, who conveys the prevailing perception of this issue among Serbian general public.

Thus all the cartoons, particularly those illustrating the SCHOOL and LIQUID scenarios, give evidence of the highly ideological and evaluative function of metaphor and other cognitive instruments in the field of Serbian EU accession media discourse viewed through the prism of the Kosovo issue. More specifically, visual and verbal realisations of the given metaphor scenarios, as displayed by the selected political cartoons, foreground the authoritative, demanding figure of the EU (as a teacher or an umpire) and defiant and unruly character of Serbia (as a student or runner). The identified multimodal cognitive devices thus help shape both group and national identities and actually help perpetuate a particular construal of reality which appears to be based on "group control" (Musolff 2000: 105) and inequality in power relations.

\section{CONCLUSION}

In this paper we have attempted to explore the role of metaphor, metonymy and image schemas in structuring Serbia-EU relations in the genre of political cartoons, viewed from the multimodal cognitive-linguistic perspective. The analysis of the selected scenarios SCHOOL, SPORT, JOURNEY, and LIQUID, depicting the tangled relations between Serbia and the EU, particularly over the highly argumentative Kosovo topic, attests to the potential of cognitive instruments in multimodal discourse not only to represent profoundly abstract and problematic phenomena in terms of something "more easily imaginable" (El Refaie 2003: 84), but also to effectively communicate the message even without verbal anchoring. This particularly refers to metonyms which function as symbols and carry strong cultural and evaluative connotations. Overall, monomodal and multimodal metaphors as used in the genre of political cartoons depicting Serbia-EU relations may be 
understood to relay a critical voice of the general public and thus become a vehicle which the cartoonist can use to set the social agenda.

Acknowledgement: A much shorter version of this paper was presented at the $11^{\text {th }}$ RaAM conference held at Freie Universität in Berlin, Germany, 1-4 July, 2016. The second author acknowledges funding from project no. 178002 Languages and cultures in space and time, funded by the Ministry of Education, Science and Technological Development of the Republic of Serbia.

\section{REFERENCES}

Barcelona, A., (ed.) (2000), Metaphor and Metonymy at the Crossroads. A Cognitive Perspective, Mouton de Gruyter, Berlin.

Benczes, R., Barcelona, A., and Ruiz de Mendoza Ibáñez, F. J., (eds.) (2011), Defining Metonymy in Cognitive Linguistics: Towards a Consensus View, John Benjamins Publishing Company, Amsterdam/Philadelphia.

Bounegru, L., and Forceville, C., (2011), "Metaphors in Editorial Cartoons Representing the Global Financial Crisis", Visual Communication 10, Vol. 2: pp. 209-229.

Charteris-Black, J., (2004), Corpus Approaches to Critical Metaphor Analysis, Palgrave, Basingstoke.

Đurović, T., and Silaški, N., (2014), "The TEACHER-STUDENT Metaphor in Serbian EU Accession Discourse A Case of Cognitive Marginalization", In: Mišić-Ilić, B., Lopičić, V., (eds.), Jezik, književnost, marginalizacija: Jezička istraživanja [Language, Literature, Marginalization: Language Explorations], pp. 47-59, Filozofski fakultet, Niš.

El Refaie, E., (2003), "Understanding Visual Metaphor: The Example of Newspaper Cartoons", Visual Communication 2, Vol. 1: pp. 75-95.

El Refaie, E., (2009a), "Metaphor in Political Cartoons: Exploring Audience Responses", In: Forceville, C. and Urios-Aparisi, E., (eds.) Multimodal Metaphor, pp. 173-197, Mouton de Gruyter, Berlin/New York.

El Refaie, E., (2009b), "Multiliteracies: How Readers Interpret Political Cartoons", Visual Communication 8, Vol. 2: pp. 181-205.

Forceville, C., (1994), "Pictorial Metaphor in Advertisements", Metaphor and Symbolic Activity 9: pp. 1-29.

Forceville, C., (1996), Pictorial Metaphor in Advertising, Routledge, London.

Forceville, C., (2005), "Addressing an Audience: Time, Place, and Genre in Peter Van Straaten's Calendar Cartoons", Humor: International Journal of Humor Research 18: pp. 247-278.

Forceville, C., (2007), "Multimodal Metaphor in Ten Dutch TV Commercials", Public Journal of Semiotics 1, Vol. 1: pp. 19-51.

Forceville, C., (2008), "Metaphor in Pictures and Multimodal Representations", In: Gibbs, R. W. Jr., (ed.), The Cambridge Handbook of Metaphor and Thought, pp. 462-482, Cambridge University Press, Cambridge.

Forceville, C., (2009), "Course on Pictorial and Multimodal Metaphor", URL: http://www.chass.utoronto.ca/ epc/srb/cyber/cyber.html [26/09/2011]

Forceville, C., and Urios-Aparisi, E. (2009), "Introduction", In: Forceville, C. J. and Urios-Aparisi, E., (eds.), Multimodal Metaphor, pp. 3-17, Mouton de Gruyter, Berlin/New York.

Gibbs, R., (2011), "Evaluating Conceptual Metaphor Theory", Discourse Processes 48, Vol. 8: pp. 529-562.

Johnson, M., (1987), The Body in the Mind: The Bodily Basis of Meaning, Imagination, and Reason, University of Chicago Press, Chicago.

Kövecses, Z., (2002), Metaphor. A Practical Introduction, Oxford University Press, Oxford.

Kövecses, Z., (2005), Metaphor in Culture. Universality and Variation, Cambridge University Press, Cambridge.

Kövecses, Z., (2008), "Conceptual Metaphor Theory: Some Criticisms and Alternative Proposals", Annual Review of Cognitive Linguistics 6, Vol. 1: pp. 168-184.

Lakoff, G., (1987), Women, Fire, and Dangerous Things. What Categories Reveal about the Mind, University of Chicago Press, Chicago.

Lakoff, G., (1993), "The Contemporary Theory of Metaphor", In: Ortony, A., (ed.), Metaphor and Thought, pp. 202-251, Cambridge University Press, Cambridge.

Lakoff, G., and Johnson, M., (1980), Metaphors We Live By, University of Chicago Press, Chicago/London.

Musolff, A., (2000), Mirror Images of Europe: Metaphors in the Public Debate about Europe in Britain and Germany, Iudicium, München.

Musolff, A., (2006), "Metaphor Scenarios in Public Discourse", Metaphor and Symbol 21, Vol. 1: pp. 23 -38. 
Negro Alousque, I., (2013), "Visual Metaphor and Metonymy in French Political Cartoons", Resla 26: pp. 365-384

Panther, K.-U., and Radden, G., (1999), Metonymy in Language and Thought, John Benjamins, Amsterdam/Philadelphia.

Radden, G., and Kövecses, Z., (1999), "Towards a Theory of Metonymy", In: Panther, K.-U. and Radden, G., (eds.), Metonymy in Language and Thought, pp. 17-59, John Benjamins, Amsterdam/Philadelphia.

Ruiz de Mendoza Ibáñez, F. J., (1997), "Metaphor, Metonymy and Conceptual Interaction", Atlantis XIX, Vol. 1: pp. 281-295.

\section{MULTIMODALNOST I KONSTRUISANJE STVARNOSTI \\ U POLITIČKIM KARIKATURAMA NA PRIMERU MEĐUSOBNIH ODNOSA SRBIJE I EVROPSKE UNIJE}

Pod okriljem kognitivne teorije metafore (Lakoff \& Johnson 1980; Johnson 1987; Charteris-Black 2004; Musolff 2006; Benczes, Barcelona, \& Ruiz de Mendoza Ibáñez 2011; itd.) i multimodalnosti (Forceville 1996, 2008; Forceville \& Urios-Aparisi 2009; Bounegru \& Forceville 2011; itd.) rad se bavi temom međusobnih odnosa Srbije i EU u medijskom vizuelnom i multimodalnom diskursu $i$ načinima obrade ove teme putem metafore u žanru novinske karikature. Analiza se zasniva na 15 karikatura objavljenih u Politici u periodu između 2009. i 2015. godine koje prikazuju odnose između EU i Srbije, kao i druga s tim povezana politička i društvena pitanja. Koristeći analitički model preuzet od Bunegri i Forsvila (2011), namera nam je da pokažemo kako se uz pomoć vizuelnih i multimodalnih metafora $i$ drugih kognitivnih instrumenata realizuje nekoliko metaforičkih scenarija (PUTOVANJA, ŠKOLE, SPORTA $i$ TEČNOSTI) putem kojih se u političkim karikaturama prikazuju međusobni odnosi Srbije i EU, kao i da ukažemo na multimodalni diskurs kao moćno sredstvo retoričkog uticaja i prenošenja evaluativnog sadržaja unutar konkretnog društveno-političkog konteksta.

Ključne reči: multimodalna metafora, političke karikature, srpski jezik, odnosi Srbije i EU 